Volume 7, Number 1, 2021

\title{
Analysis of Computer Modelling Results on Fuel Rods Strength and Condition at Reduced or Absent Cooling Caused by Accident
}

\author{
Stepan Lys ${ }^{*}$ \\ Lviv Polytechnic National University, 12 S. Bandery St., Lviv, 79013, Ukraine
}

Received: January 05, 2021. Revised: February 17, 2021. Accepted: February 23, 2021.

() 2021 The Authors. Published by Lviv Polytechnic National University.

\begin{abstract}
The paper describes the phenomenology of fuel rod behaviour in severe accident. As an example, an experiment is described resulting in severe damage of 19 fuel rod assembly of VVER type; it was carried out in the CORA facility in 1993 (Research Centre, Karlsruhe, Germany). Testing conditions and results of post-test investigations of fuel assembly are given. The fuel rod code RAPTA-SFD is briefly dealt with; the code was a participant in the International Standard Problem ISP-36. The basic results are presented acquired by computer modelling CORA-W2 experiment using RAPTA-SFD code. Among the presented experimentally acquired and calculated results, the scope of the data on stainless steel component behaviour is substantial. The tested CORA-W2 fuel assembly contained a significant quantity of steel components, viz., spacer grids, a guide thimble, and a cladding of an absorber element. It is to be borne in mind that the spacer grids and a guide thimble of the updated and upgraded fuel assembly of VVER1000 are fabricated from $\mathrm{Zr}$-alloy, hence, the relative quantitative characteristics of chemical interactions between materials and stainless steel ( $\mathrm{Cr}-\mathrm{Ni}$ alloy) will be much lower for the up-to-date upgraded fuel assembly under identical conditions.
\end{abstract}

Keywords: fuel rod; absorber; severe accident; chemical interaction; uraniumdioxide.

\section{Statement of the research problem}

The objective of analyzing fuel rod behaviour in the most severe design basis accidents is to validate the requirement not to exceed the maximal design limit placed on fuel rod damage by PBYA RU AS-89 [1] as well as the safety criteria that limit fuel rod damage in RIA (reactivity initiated accident):

- maximal cladding temperature not higher than $1200^{\circ} \mathrm{C}$;

- maximal depth of rust on cladding not more than $18 \%$ of its initial thickness;

- steam reacted zirconium in core not more than $1 \%$ of its mass in fuel rod claddings;

- fuel rod melt-down is not tolerated;

- maximal radius averaged enthalpy of fuel not more than $230 \mathrm{cal} / \mathrm{g}$.

In a severe beyond the design basis accident, these limits may be exceeded.

As far as beyond the design basis accident, the designs of RP (reactor plant) and NPP (nuclear power plant) have to contemplate measures that would manage those accidents, actions attenuating the consequences.

To work out measures for accident management, one has to gain knowledge of the behaviour of core and its components under severe accident conditions: the knowledge is acquired in experimental investigations and computer modelling.

${ }^{*}$ Corresponding author. Email address: stepan.s.lys @ lpnu.ua

This paper should be cited as: S. Lys. Analysis of computer modelling results on fuel rods strength and condition at reduced or absent cooling caused by accident. Energy Engineering and Control Systems, 2021, Vol. 7, No. 1, pp. 7 - 16. https://doi.org/10.23939/jeecs2021.01.007 


\section{Analysis of the recent publications and studies}

The model of a single water cooled power reactor fuel rod failure in accident attended with severe fuel damage is of significance being an element of the overall model of a core behaviour that describes the initial stage of destruction [1]-[3].

The basic distinctions in the state of fuel rods (and absorber elements) in severe beyond the design basis accident are caused by a higher temperature level and consist in the following [1], [3]-[5]:

1) zirconium-steam reaction becomes a serious source of heat and may result in a drastic temperature rise;

2) mechanisms of fuel rod damage (oxidation, ballooning, loss of tightness by cladding), specific for design basis accidents, are supplemented by fuel rod material melting that distorts the rod shape of fuel rods;

3) reactions between core materials proceed in an intensive manner, namely, eutectic fuel-cladding and cladding-spacer grid elements interactions, dissolution of fuel with molten zirconium and zirconium with molten stainless steel, and steel-boron carbide interaction;

4) melt and solid fragments of fuel rod materials as well as products of chemical interactions while relocating to the bottom are able of blocking the flow cross section area in a group of fuel rods to form an energy releasing corium.

In CORA, tests (Germany) were implemented using two VVER type fuel assemblies under conditions simulating a severe accident attended with melting down core components (CORA-W1, CORA-W2) [3]-[6]. The fuel assemblies were 19-rod bundles of electrically heated fuel rod simulators having a $1 \mathrm{~m}$ fuel column. In CORA-W2, one fuel rod was replaced by a boron carbide absorber. Based on the CORA-W2 experiment, the International Standard Problem ISP-36 was organized the objective of which was to check the quality of modelling fuel rod bahaviour under severe conditions using the available computer codes. The participants of ISP-36 made an attempt to adapt the alien codes (versions of codes ATHLET, ICARE, SCDAP/RELAP, MELCOR, etc.) to calculate the experiment with VVER fuel. Among the 21 official participants, 8 members represented Russia with the only one domestic code being the program RAPTA-SFD created as a result of serious upgrading the RAPTA-5 code. The ISP36 participants carried out "blind" and open (corrected) calculations of the CW-2 experiment; procedures were developed and mastered, and materials science examinations of assembly fragments were implemented.

\section{Aim of the research}

The objective of analyzing fuel rod behaviour in the most severe design basis accidents is to validate the requirement not to exceed the maximal design limit placed on fuel rod damage as well as the safety criteria that limit fuel rod damage in reactivity initiated accident.

\section{Description of experimental conditions simulating accident with core materials melting (CORA-W2)}

The objective of this experiment was the investigation of the behaviour type PWR fuel element (VVER-1000) during early core degradation [3]-[5].

\subsection{Description of the CORA test facility}

The CORA out-of-pile facility is designed to investigate the behaviour of LWR fuel assemblies under severe fuel damage accident conditions. In the experiments the decay heat is simulated by electrical heating. Great emphasis is placed on the fact that the test bundle contains the original materials used in light-water reactor fuel elements to investigate the different material interactions.

Pellets, cladding, grid spacers, absorber rods and channel box walls are typical of those of the investigated LWR type with respect to their compositions and radial dimensions. In test CORA-W2 original $\mathrm{UO}_{2}$-pellets, $\mathrm{Zr} 1 \% \mathrm{Nb}$ cladding, SS-spacers, $\mathrm{B}_{4} \mathrm{C}$ absorber inside stainless steel cladding and stainless steel guide tube and $\mathrm{Zr} 1 \% \mathrm{Nb}$ channel box walls are used.

Bundle and surroundings of the CORA facility are shown in Fig. 1 [5].

The central part of the facility is the fuel rod bundle. The bundle is enclosed in a $\mathrm{Zr} 1 \% \mathrm{Nb}$ shroud with $\mathrm{ZrO}_{2}$ fibre insulation. A high temperature radiation shield surrounds the bundle and shroud assembly. The massive insulation provides a realistic flat radial temperature gradient. The bundle is connected to the power supply system at 
the upper and lower ends. The water-filled quench cylinder provides the cooling of the lower end bundle electrodes. The bundle upper end is fixed in the bundle head plate [4].

The steam is produced in the steam generator. Together with the additional argon it is superheated and guided to the lower end of the bundle. The steam not consumed within the bundle is condensed in two parallel condensers and the remaining hydrogen argon mixture is fed into the off-gas system after dilution by air to a low hydrogen concentration [4].

\subsection{Bundle design}

The bundle cross section is shown in Fig. 2. Test bundle CORA-W2 consisted of 19 fuel rod simulators. The test rods were arranged within the bundle as shown in Fig. 2. Thirteen of the 19 fuel rods were electrically heated (active) by central tungsten heating elements. Five rods were unheated (passive) and one position within the bundle was filled with an absorber rod and its pertinent guide tube. The active rods as well as the passive rods were filled with annular $\mathrm{UO}_{2}$ pellets of the same outer diameter but with different sized central holes $(4.2 \mathrm{~mm}, 2.4 \mathrm{~mm})$. The rod cladding is made of zirconium -1\% niobium alloy ( $\mathrm{Zr} 1 \% \mathrm{Nb})$. Three stainless steel grid spacers of $20 \mathrm{~mm}$ depth were mounted into the bundle at $-5 \mathrm{~mm}, 210 \mathrm{~mm}$ and $610 \mathrm{~mm}$ elevations (upper edge) [4].

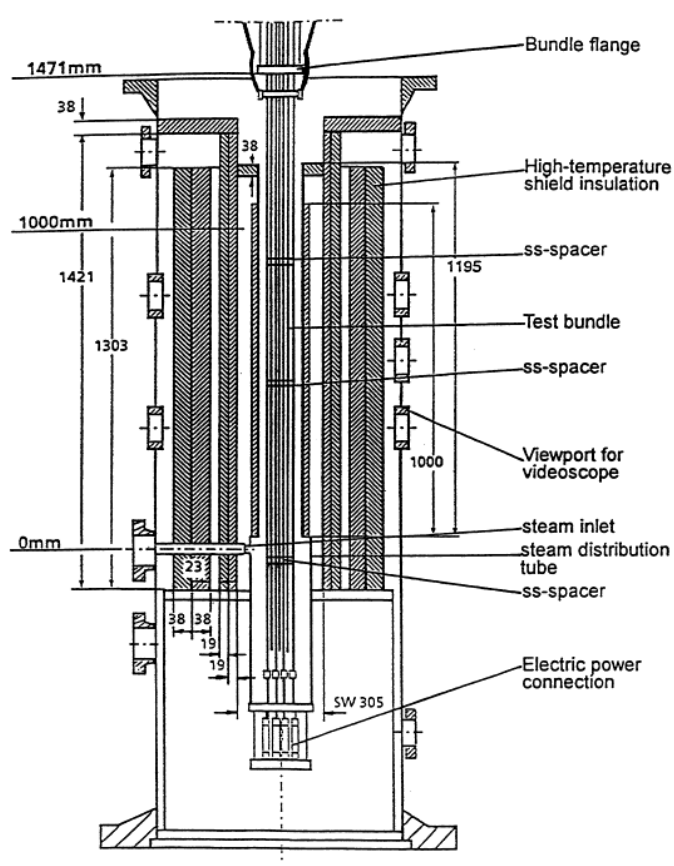

Fig. 1. CORA bundle arrangement

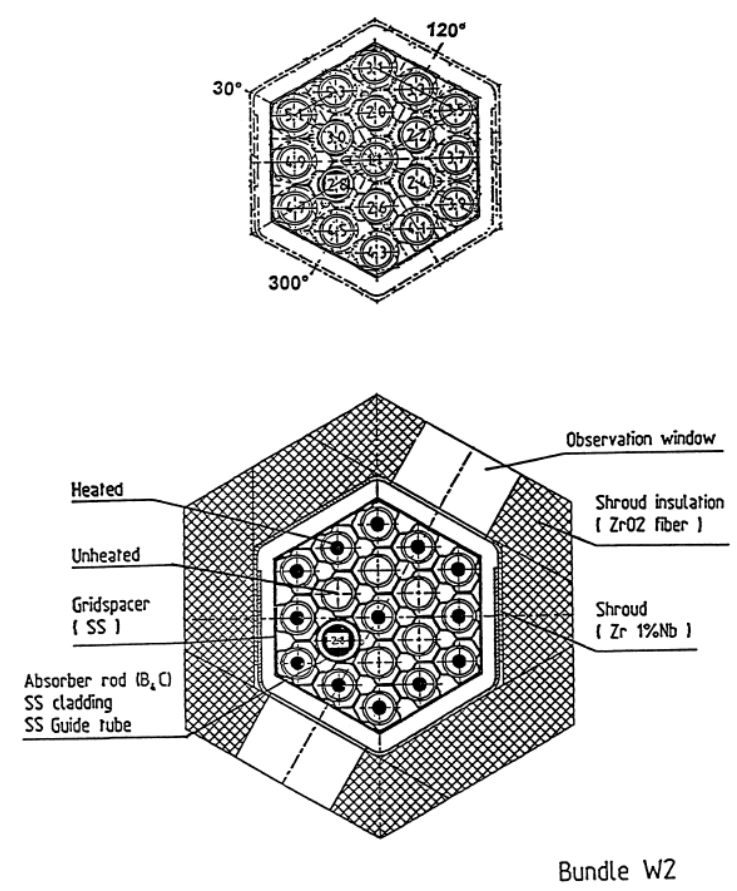

Fig. 2. Cross section of experimental bundle CORA-W2

The shroud surrounding the bundle is also made of $\mathrm{Zr} 1 \% \mathrm{Nb}$ and insulated with a $20 \mathrm{~mm}$ thick layer of $\mathrm{ZrO}_{2}$ fibre material to guarantee a uniform radial temperature distribution. Two videoscopes, at $600 \mathrm{~mm}$ and $800 \mathrm{~mm}\left(120^{\circ}\right.$ orientation) were used in test CORA-W2 to observe the materials behaviour and the relocation of material during transient testing. The windows in the shroud and insulation are closed by quartz windows [4].

The hydrogen produced during the test by the steam/zirconium reaction was measured by a two mass spectrometer system in the mixing chamber after the gas had passed the condenser [4].

\section{Description of post-test investigation results}

\subsection{Post-test appearance of the bundle and of cross sections}

The appearance of W2-bundle after the test is shown in Fig. 3 [5]. Below $300 \mathrm{~mm}$ the shroud preserved its geometric form with increasing oxidation above $200 \mathrm{~mm}$ elevation. From $300 \mathrm{~mm}$ to $700 \mathrm{~mm}$ the shroud is deformed and contains many cracks and holes. Up to about $1100 \mathrm{~mm}$ elevation the shroud was attacked so much, that it 
disappeared during dismantling of the insulation. The test bundle is fairly intact up to an elevation of about $200 \mathrm{~mm}$. The severely oxidized part of the bundle lies above $400 \mathrm{~mm}$. The upper grid spacer has completely molten away due to chemical interactions with the $\mathrm{Zr} 1 \% \mathrm{Nb}$ cladding and by reaching the melting point, while the central grid spacer has survived in accordance with the axial temperature profile. The absorber rod failed at about $210 \mathrm{~mm}$ (i.e. above this elevation the absorber rod has disappeared). A blockage has formed at about $200 \mathrm{~mm}$. Interaction of the melt with the UO-pellets can be recognized. The radial deformation of the cladding, the so-called "flowering" is evident from about $400 \mathrm{~mm}$ upward. For post-test investigations the bundle was filled with epoxy and then cut in the crosssectional direction. More detail description of three bundle cross sections is given below [4].

\subsection{Bundle Elevation $141 \mathrm{~mm}$ (bottom)}

At this elevation the bundle is devoid of any visible damages (Fig. 4) [5]. However, some specificity is to be noted. The fuel simulator bundle is displaced relative to the assembly shroud. This is likely to reflect the bundle status prior to the experiment, but it is more probable that this displacement is due to bundle damages in the top sections during the experiment. There are three parts of the total area of $51 \mathrm{~mm}^{2}$ filled with molten metal. There is no boron carbide in the absorber rod. This is likely to be explained by boron carbide powder tipping out during the cutting of the bundle into specimens. No traces of interaction between boron carbide and stainless steel or oxidation of fuel simulator claddings and bundle shroud were found out.

Cracks were available in some $\mathrm{UO}_{2}$ pellets. Some pellets have no fuel fragments. However, this crumbling is not related to the fuel damage during the experiment, it is most probable to occur during bundle cutting or preparation of section.

The microstructures of fuel simulator claddings, shroud, absorber rod claddings, guide tube and fuel pellets do not essentially differ from the structures of the materials prior to the experiment.

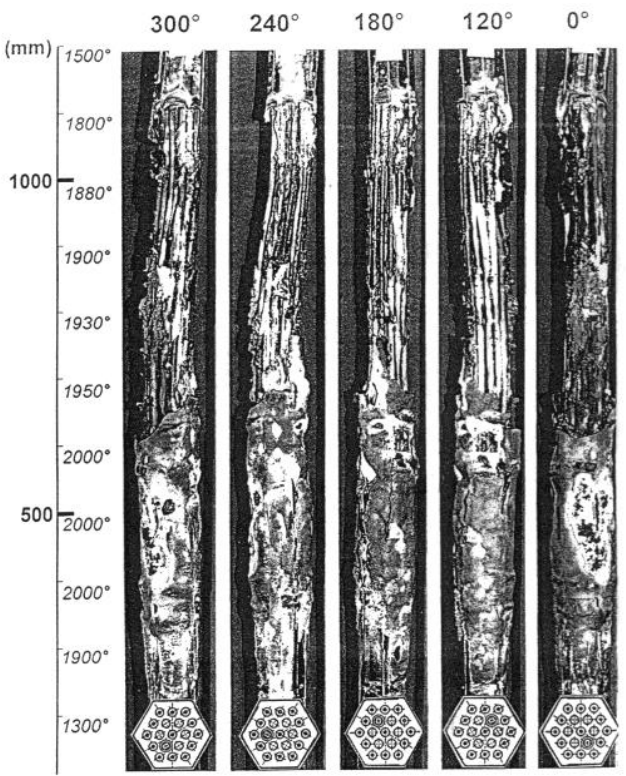

Fig. 3. Post-test view of bundle CORA-W2 after experiment

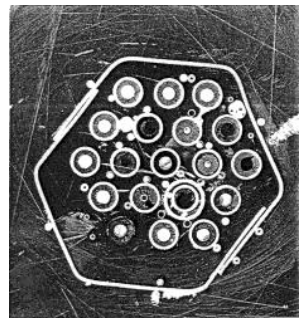

Fig. 4. Horizontal cross section of bundle, elevation $141 \mathrm{~mm}$ (bottom)

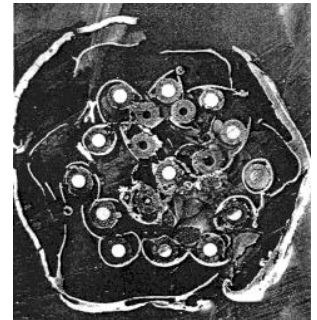

Bundle

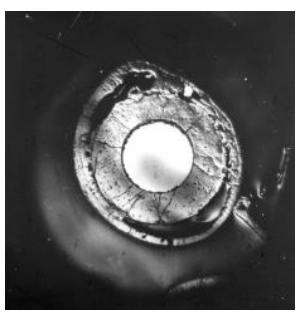

Simulator 5.1

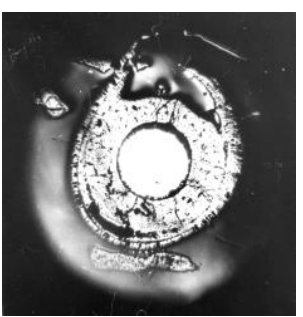

Simulator 3.7

Fig. 5. Horizontal cross section of bundle and simulators, elevation $498 \mathrm{~mm}$ (bottom) 


\subsection{Bundle Elevation $498 \mathrm{~mm}$ (bottom)}

At this elevation the bundle is strongly damaged (Fig. 5) [5]. However, the fuel pellets of all 18 rods are available and their damage can be characterized as insignificant. The absorber rod and its guide tube are missing. There are three boron carbide fragments of the total area of $60 \mathrm{~mm}^{2}$. Boron carbide is impregnated with a metallic melt containing iron, zirconium, uranium and other elements. These fragments are likely to have been relocated from the top sections and they cannot be identified as B4C that belongs to this section.

The fuel simulator claddings have been badly damaged. In some rods they are essentially missing. The characteristic cross-sections of the rods are illustrated in fig. 5. The outer layer of the rod consists seemingly of two layers. The outer layer is zirconium dioxide that resulted from the interaction between the cladding material in the solid state and steam. The second layer is a phase containing in the main zirconium, oxygen, uranium and insignificant amounts of iron and chromium. Within a single rod cladding over the azimuth thickness of $\mathrm{ZrO}_{2}$ varies in a wide range (the maximum thickness of $\mathrm{ZrO}_{2}$ reaches $0.6 \mathrm{~mm}$ ). The causes of this can be different. First, nonuniform temperature field of cladding; second, cladding deformation; third, possible separation of oxide films.

The bundle shroud in the section has significant damages. The thickness sometimes reaches $3 \mathrm{~mm}$. As it has been shown by the X-ray spectral microanalysis (CAMECA) there appeared uranium and iron over the whole shroud thickness for the exception of the outer and inner layers of $\mathrm{ZrO}_{2}$. In some points the mass content of uranium attains $20-50 \%$. It is likely that formation of low melting eutectics (U-Zr), (Fe-Zr), (U-Fe) is a cause of some parts of shroud melting down and separation of a thin internal part of $\mathrm{ZrO}_{2}$. At the sites where the inner and outer layers of $\mathrm{ZrO}_{2}$ are retained, one can observe a two phase region between them, that contains particles having different contents of $\mathrm{Zr}, \mathrm{U}$ and $\mathrm{O}$. Visually the specimen plane has a metallic shine of various intensity therefore it cannot be attributed to a ceramic phase.

\subsection{Bundle Elevation $964 \mathrm{~mm}$ (bottom)}

At this elevation the bundle is badly damaged (Fig. 6). Essentially there is no bundle shroud. There is but a thin layer of $\mathrm{ZrO}_{2} 6 \mathrm{~mm}$ long. The fuel pellets are significantly displaced relative to their initial position. However, changes in the area occupied by $\mathrm{UO}_{2}$ are small.

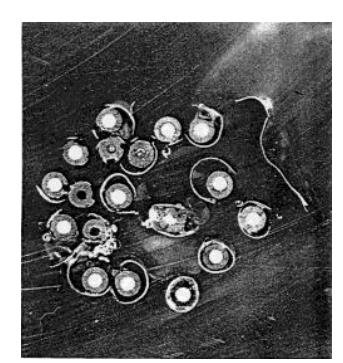

Fig. 6. Horizontal cross section of bundle, elevation $964 \mathrm{~mm}$ (bottom)

Five rods have essentially no claddings. The absorber rod array is completely missing. The section contains an insignificant amount of molten metal and rather a small amount of ceramic materials.

\section{RAPTA-SFD code modelling of the VVER-1000 fuel rod bundle behaviour in CORA-W2 experiment}

\subsection{Brief description of the RAPTA-SFD code}

Model of damage of a single fuel element of water-cooled power reactor in conditions of accident with severe damage of fuel is important as an element of the general model of damage of the active zone of a reactor describing the first stage of the latter. The object of RAPTA-SFD calculation analysis is a single fuel element (simulator or absorber) of a rod type.

RAPTA-SFD code [5], [6] is developed basing on RAPTA-5 version intended for calculation of fuel elements behavior in design accident modes through including of the following models:

- boundary conditions for heat balance ( related to modeling of special experiments, for example CORA-W2);

- model of heat and mass transfer at melting; 
- model of boron carbide absorber element with stainless steel cladding;

- models of high-temperature chemical interaction of basic materials of the VVER active zone.

In the code the numerical integration algorithm of the non-stationary equations system of heat balance for elementary volumes of multi-layered cylindrical domain is implemented taking into consideration variations of its geometry at each time step. Geometric variations account for thermal elastic deformations of fuel and cladding, creep deformations of the cladding, building up of layers of chemical interactions of materials and displacement of melt. Axial digitization of a cylindrical domain can be arbitrary. The problem is solved in axial-symmetric formulation. Within each axial region all parameters describing the state of simulation are assumed independent of the axial coordinate.

Phenomenological model of melt displacement uses conservation laws for mass and heat. Displacement of a melted volume is simulated through variation of lengths and temperatures of corresponding layers of a cylindrical domain within the boundaries of adjacent axial regions.

Model of boundary conditions on the outer surface of a simulation takes into consideration convection heat exchange with the stream of single-phase coolant (steam, steam/argon mixture) and radiation heat exchange with surrounding surfaces. Simulation of a 19-rod CORA-W2 assembly was carried out by means of iterative calculations for single representative simulator from periphery to centre and vice versa. With this, calculation for outer layer simulator was carried out simultaneously with calculations of multi-layered heat insulation shroud of the assembly [5].

Results of RAPTA-SFD calculations are arranged in compliance with requirements of ISP-36 and they include large information concerning energy balance, temperature mode, local and integral characteristics of chemical interactions and displacements of melted volumes.

Usage in this code version of simple phenomenological models for description of interrelated chemical and physical processes enable one to flexibly alter code structure and to rapidly assess the condition of the fuel. These models imply expert setting of some parameters that can be determined from the results of experimental investigations. The above applies to a considerable extent to simulation of high-temperature chemical interactions of basic VVER active zone materials in accident conditions with severe damage of fuel.

\subsection{Models of high-temperature chemical interactions}

Phenomenological models of chemical interactions [5] use parabolic dependence of the measure of reaction $W$ on time $t$ at isothermal conditions:

$$
W^{2}=K_{p} \cdot t
$$

where $K_{p}=A \cdot \exp (-B / T) ; A, B$ are empirical coefficients; $T$ is temperature, $\mathrm{K}$.

Kinetics of the reaction in non-isothermal conditions is determined from a recurrent relation taking into account previous reaction history.

The following chemical reaction models are implemented in RAPTA-SFD code:

- oxidation of $\mathrm{Zr} 1 \% \mathrm{Nb}$ in steam (actual dependence);

- interaction of $\mathrm{Zr} 1 \% \mathrm{Nb}$ with $\mathrm{UO}_{2}$;

- oxidation of stainless steel X18H10GT in steam;

- interaction of stainless steel with $\mathrm{B}_{4} \mathrm{C}$;

- interaction of $\mathrm{Zr} 1 \% \mathrm{Nb}$ with stainless steel;

- dissolution of $\mathrm{UO}_{2}$ by melted zirconium.

Empiric coefficients of these models have been determined from the results of laboratory experimental investigation of chemical interaction in temperature range specific for severe accidents.

The most reliable measure of steam/zirconium reaction is weight increase of oxygen per unit surface area determined by oxidation of fuel cladding samples. The absorbed oxygen forms a layer of stoichiometry zirconium dioxide and a layer of $\alpha-\mathrm{Zr}$ stabilized by oxygen. The layer depths can be used as a measure of reaction also. In the result of the reaction hydrogen is liberated, the amount of this hydrogen is determined on the basis of 
reaction equation. Rate of hydrogen liberation by a structure being oxidized is determined via integration over the structure active surface (assembly of fuel elements and shroud). Heat production of steam/zirconium reaction is estimated as ca. $6.5 \mathrm{MJ} / \mathrm{kg} \mathrm{Zr}$ which causes strong influence of steam/zirconium reaction to temperature mode, especially at temperatures above $1500{ }^{\circ} \mathrm{C}$ when acceleration of reaction occurs due to alteration of oxide film structure.

Eutectic interaction of uranium dioxide with $\mathrm{Zr} 1 \% \mathrm{Nb}$ alloy (as well as with zircalloy) results to creation of three specific layers. In those layers intermetallic inclusions ( $\mathrm{U}, \mathrm{Zr}$ ) can exist in liquid state at relatively not high temperatures. However, within the period from the onset of this reaction to achieving of cladding melting point (characteristic for CORA-W2 experiment), layers of considerable thickness do not manage to build up.

Stainless steel oxidation rate is comparable to the rate of steam/zirconium reaction. This reaction can also lead to hydrogen release, the measure of reaction used being the specific weight increase of oxygen. Analysis of specific oxidation heats value enables one to conclude that the heat effect of this reaction is an order of magnitude less than that for steam/zirconium one.

Interaction of stainless steel with boron carbide leads to propagation of interaction layer mainly into the depth of the cladding. This leads to emerging of fusible eutectics. Experiments on samples have shown that melting occurs at the temperature of $1200{ }^{\circ} \mathrm{C}$ (melting point of chromium/nickel steels of austenite class constitutes 1400 to $1425{ }^{\circ} \mathrm{C}$ ). The melt of absorber element is occurred significantly early than fuel element. The remained boron carbide, evidently, partially flakes off and partially is dissolved in melt. Melt of the absorber element coming to adjacent fuel elements and initiating the reaction of zirconium dissolution. It is simulated in RAPTA-SFD code using kinetics of solid interaction of $\mathrm{Zr} 1 \% \mathrm{Nb}$ with stainless steel.

$\mathrm{Zr} 1 \% \mathrm{Nb}$ alloy interaction with stainless steel (spacer grids) results in creation of interaction layers. Emerging eutectics ( $\mathrm{Zr}-\mathrm{Fe}, \mathrm{Zr}-\mathrm{Ni}$ ) have low melting point (less than $1000{ }^{\mathrm{O}} \mathrm{C}$ ) and can be sites of origin for structure melting. Existing oxide films on original materials are counteracted by this reaction.

Reaction of uranium dioxide dissolution in zirconium melt [7] is the most essential for determining of the amount and the composition of energy-releasing melt (corium). $\mathrm{UO}_{2}$ solubility in $\mathrm{Zr}$ melt is very high, and the weight concentration of the former essentially instantly reaches $35.8 \%$. A major role for integral features of interaction is played by time and scale factors.

\subsection{Modeling results of CORA-W2 experiment}

In Fig.7-Fig.12 some results of RAPTA-SFD code simulation of CORA-W2 experiment are shown [5], [8]. Three curves are presented in each figure: 1 - the plot obtained in the result of direct measurements in the course of the experiment with possible subsequent processing or in the result of post-test bundle investigation [8]; 2 - calculation curve obtained as the result of "blind" calculation within the framework of ISP-36 [6]; 3 - curve obtained as the result of final corrected calculations.

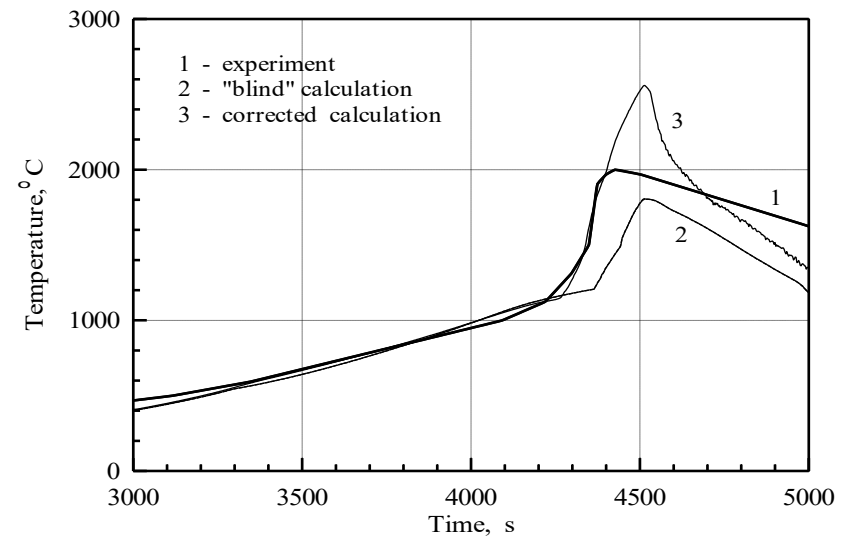

Fig. 7. CORA-W2 Experiment. Temperature mode of fuel element simulations

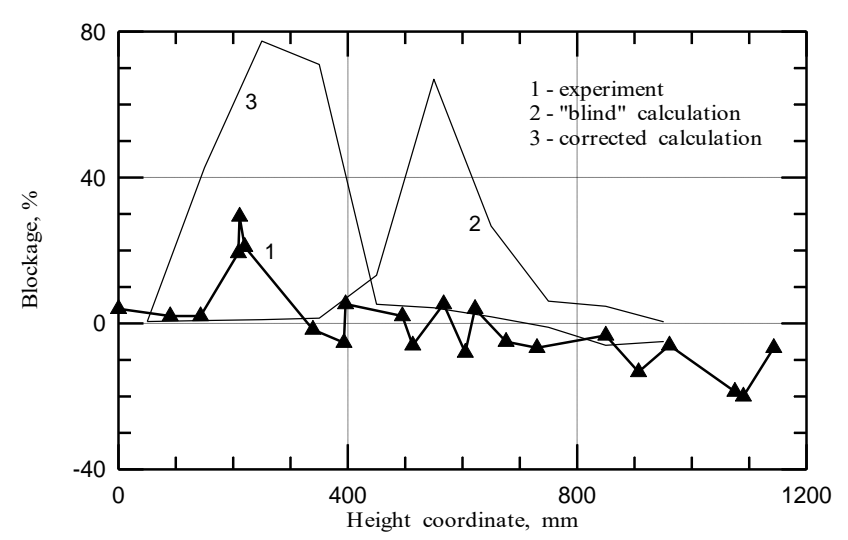

Fig. 8. CORA-W2 Experiment. Blockage distribution of height bundle cross section 


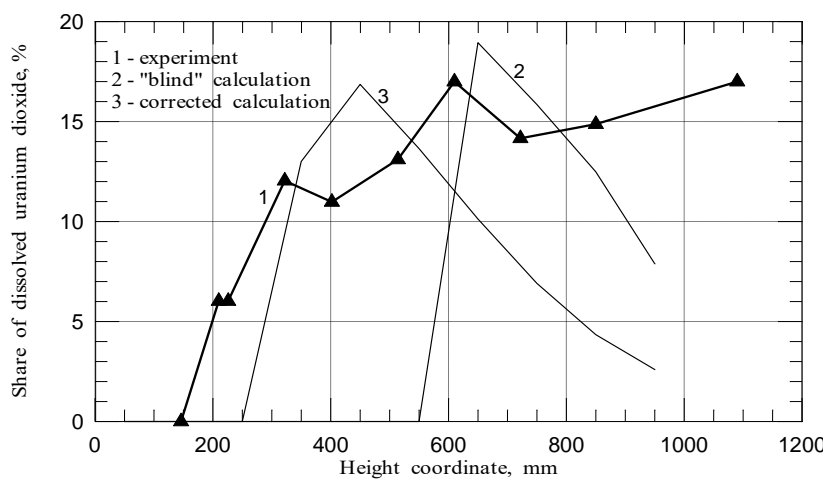

Fig. 9. CORA-W2 Experiment. Distribution of the uranium dioxide share dissolved by zirconium melt over height of the bundle

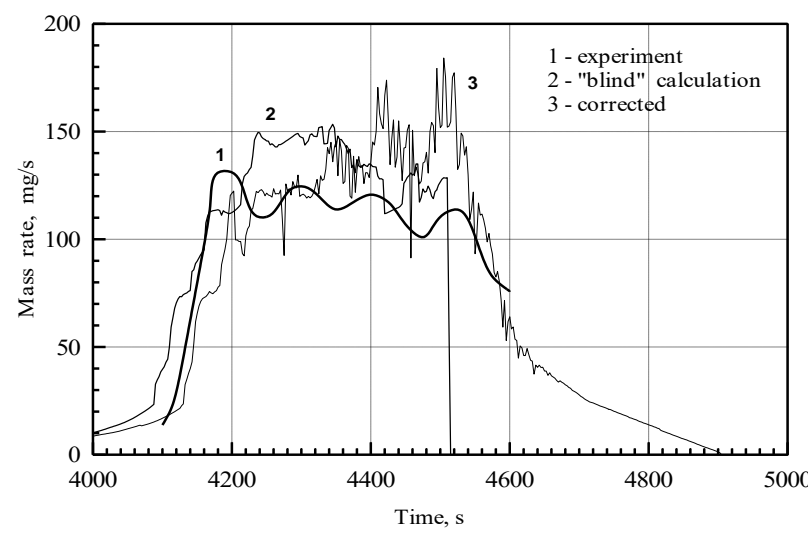

Fig. 11. CORA-W2 Experiment. Rate of hydrogen production (Bundle + Shroud)

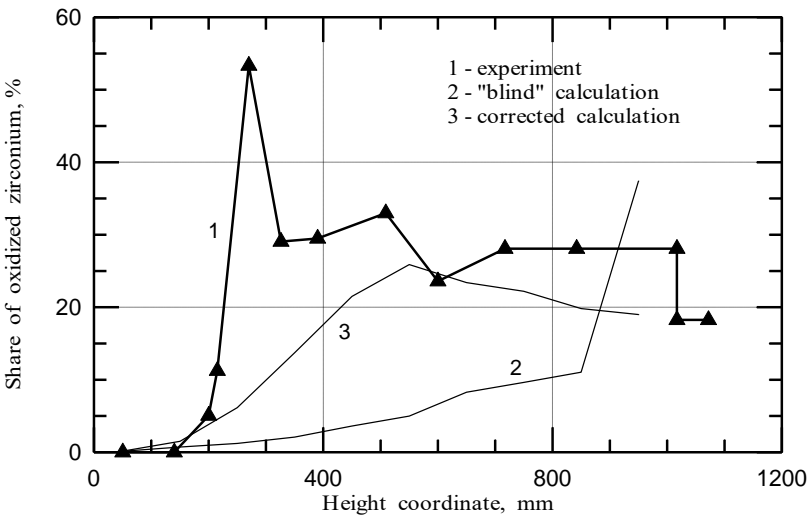

Fig. 10. CORA-W2 Experiment. Distribution of the oxidized zirconium share in original position over height of the bundle

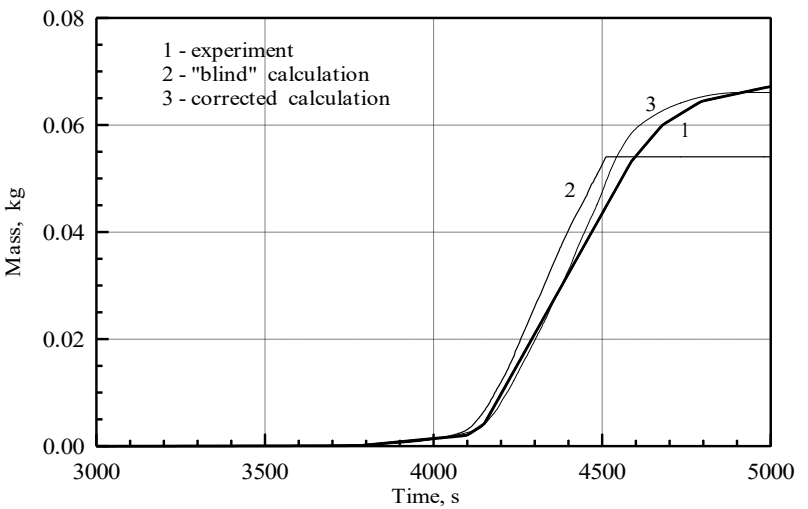

Fig. 12. CORA-W2 Experiment. Total hydrogen outlet (Bundle + Shroud $)$

As it was mentioned above, RAPTA-SFD code uses several parameters set forth from expert reasoning based on experimental information. Thus, debugging of the code for calculations under ISP-36 was carried out using the known results of CORA-W1 [5] experiment. In choice of parameter values the following factors were taken into consideration:

- uranium melting point was not reached;

- axial digitization in calculation model should not lead to considerable steps of functions describing processes of hydrogen generation and melt flow down.

One of the most important aspects of fuel behavior in condition of severe accident influencing temperature mode and degradation processes is steam/zirconium reaction. Extrapolation of oxidation law beyond the limits of temperature range of experimental data can lead to the need to account for "steam hunger". In conduction of "blind" and corrected calculation the rate of specific weight increase of oxygen was limited by the value of steam flow rate through the assembly divided by total zirconium surface area of the assembly. In corrected version the residual steam flow after valve shutting was taken into account. In the "blind" calculation it was assumed that after melt relocation onto an axial region oxidation of original zirconium in this region stops and oxidation of relocated melt continuing. In the corrected calculation oxygen weight increase in the axial region containing relocated melt was divided to original and relocated zirconium proportionally to their masses. This permitted to obtain better result in assessment of height distribution of assembly oxidized zirconium prior to its melting (Fig. 10). In both calculations fair agreement of hydrogen generation rate and of its total yield with experiment values has been obtained (Fig. 11, 12). 


\section{Conclusion}

The basic distinction of severe beyond the design basis accident conditions from design basis ones lies in the level of temperature reached. The fuel rod behaviour under severe accident conditions, as distinct from that in design basis one, is described by the following main processes:

1) Zr-steam reaction becomes a serious source of heat and may lead to a drastic temperature rise;

2) fuel rod damage mechanisms typical of design basis accidents are supplemented by fuel rod materials melting that destructs the fuel rod design;

3) intensively proceeding reactions between core materials;

4) molten and solid fragments of fuel rod materials and products of chemical interactions may block the flow cross section area in a group of fuel rods to form an energy releasing corium.

Investigation of a single fuel rod behaviour under severe accident conditions is expedient for the adequate description of the initial stage in accident evolution within a scale of a fuel assembly or core.

The RAPTA-SFD analysis of design parameters evidences the good match to the experimentally determined temperatures before the relocation of molten materials and boundaries of molten region as well as the rate of hydrogen generation via oxidation of a fuel assembly.

In the CORA-W2 experiment, the rise of the $\mathrm{Zr}$-steam reaction temperature was some $1400^{\circ} \mathrm{C}$. However, it is to be kept in mind that it is determined by the heat balance in a fuel rod at the hottest spot (power rating level, heat transfer conditions - flow rate, flow cross section area etc). According to [2], the ultimate temperature for design basis accidents is established to be $1200^{\circ} \mathrm{C}$.

The assessed parameters of chemical interactions between materials under conditions of molten mass relocation proved to be less accurate. Those processes influence the quantity of molten mass, its consequences and energy release, hence, the feasibility of its cooling.

Among the presented experimentally acquired and calculated results, the scope of the data on stainless steel component behaviour is substantial. The CORA-W2 tested fuel assembly contained a significant quantity of steel components, viz., spacer grids, a guide thimble, and a cladding of an absorber element. It is to be borne in mind that the spacer grids and a guide thimble of the updated and upgraded fuel assembly of VVER-1000 are fabricated from $\mathrm{Zr}$-alloy, hence, the relative quantitative characteristics of chemical interactions between materials and stainless steel (Cr-Ni alloy) will be much lower for the up-to-date upgraded fuel assembly under identical conditions.

\section{References}

[1] Nuclear safety rules for nuclear power plants. PBYA RU AS-89. PNAE G-1-024-90. (in Russian)

[2] General provisions for ensuring the safety of nuclear power plants OPB-88/97. NP-001-97 (PNAE G-01-011-97). Approved by the Resolution of the Gosatomnadzor of Russia N9 of 11/14/97. (in Russian)

[3] Firnhaber M., Trambauer K., Hagen S., Hofmann P., Yegorova L. Specification of the International Standard Problem ISP36: CORA-W2 Experiment on Severe Fuel Damage. February 1994.

[4] International Standard Problem ISP-36: CORA-W2 Experiment on Severe Fuel Damage for a Russian Type PWR. Comparison Report. OCDE/GD(96)19, GRS-120, FZKA 5711.

[5] NPP "KUDANKULAM" Unit 1,2. Topical report «Results of computer modelling fuel rods strength and condition in accidents attended with deteriorated cooling or loss of coolant (postulation cladding temperature rise up to melting point)» SE VNIINM, 2001.

[6] Bibilashvily Yu.K., Sokolov N.B., Salatov A.V., Andreyeva-Andrievskaya L.N., Nechaeva O.A., Vlasov F.Yu. Features of RAPTA-SFD code modelling of chemical interactions of basic materials of the VVER active zone in accident conditions with severe fuel damage. Proceedings of IAEA Technical Committee on Behaviour of LWR Core Materials under Accident Conditions, held in Dimitrovgrad, Russia, on 9-13 October 1995. IAEA-TECDOC-921, Vienna, 1996, pp. 243-252.

[7] Hofmann P., Uetsuka H., Wilhelm A.N., Garcia E.A. Dissolution of solid UO2 by molten zircaloy and its modelling. In: Severe Accidents in Nuclear Power Plants, Proceedings of a Symposium, Sorrento, 21-25 March 1988, Jointly organized by IAEA and NEA (OECD), IAEA-SM-296/1, pp. 3-17.

[8] Goryachev A., Shtuckert Yu., Zwir E., Stupina L. Post-test investigation result on the VVER-1000 fuel tested under severe accident conditions. Proceedings of IAEA Technical Committee on Behaviour of LWR Core Materials under Accident Conditions, held in Dimitrovgrad, Russia, on 9-13 October 1995. IAEA-TECDOC-921, Vienna, 1996, pp. 187-202. 


\title{
Аналіз результатів розрахункового моделювання міцності і стану твелів в умовах аварії 3 погіршеним або відсутнім охолодженням
}

\author{
Степан Лис \\ Національний університет «Львівська політехніка», вул. Степана Бандери, 12, Львів, 79013, Украӥна
}

\section{Анотація}

У статті представлена феноменологія поведінки твелів у важкій аварії. Як приклад наведено опис експерименту з важким пошкодженням 19-твельної збірки типу ВВЕР, проведеного на установці СОRА (Дослідницький Центр Карлсруе, Німеччина). Представлені умови випробування і результати посттестових досліджень збірки. Наведено короткий опис твельного коду RAPTA-SFD, який брав участь в Міжнародній Стандартній Проблемі ISP-36. Представлені основні результати розрахункового моделювання експерименту CORA-W2 3 використанням коду RAPTA-SFD. Серед представлених експериментально-розрахункових результатів значне місце займають дані по поведінці елементів 3 нержавіючої сталі. Конструкція випробуваної в експерименті CORA-W2 збірки містила значну кількість сталевих елементів: дистанціонуючі решітки, направляючий канал, оболонка поглинаючого елемента. Дистанціонуючі решітки і направляючий канал сучасної удосконаленої тепловиділяючої збірки (УТВ3) ВВЕР-1000 виготовляються 3 цирконієвого сплаву, тому відносні кількісні характеристики хімічних взаємодій матеріалів з нержавіючої сталі для сучасної УТВЗ в аналогічних умовах будуть значно нижчі.

Ключові слова: тепловиділяючий елемент; поглинаючий елемент; важка аварія; хімічна взаємодія; діоксид урану. 